\title{
KAJIAN KONSEP TEKNOLOGI PENGOLAHAN PASIR ZIRKON LOKAL YANG MENGANDUNG MONASIT, SENOTIM, DAN ILMENIT
}

\section{THE CONCEPT STUDY OF PROCESSING TECHNOLOGY OF LOCAL ZIRCON SAND CONTAINING MONAZITE, XENOTIME, AND ILMENITE}

\author{
Herry Poernomo*, Dwi Biyantoro, dan MariaVeronica Purwani \\ Pusat Teknologi Akselerator dan Proses Bahan - BATAN \\ Jalan Babarsari Kotak Pos 6101 ykbb, Yogyakarta 55281 \\ E-mail: herry-poernomo05@batan.go.id
}

Naskah diterima: 21 September 2016, direvisi:24 Oktober 2016, disetujui: 25 November 2016

\begin{abstract}
ABSTRAK
Keberadaan zirkon $\left(\mathrm{ZrSiO}_{4}\right)$ di alam kebanyakan berasosiasi dengan beberapa senyawa oksida berharga (SOB) seperti $\mathrm{TiO}_{2}$ dan oksida logam tanah jarang atau rare earth oxides (REO). Keterdapatan mineral alam di Indonesia yang mengandung zirkonium $(\mathrm{Zr})$ dan $\mathrm{REO}$ tersebar di 13 wilayah mulai dari Provinsi Aceh sampai Papua Barat. Berdasarkan hal tersebut, maka tujuan penelitian adalah melakukan kajian integrasi teknologi pengolahan pasir zirkon lokal yang mengandung $\mathrm{TiO}_{2}$ dan REO. Penelitian dilakukan dengan menganalisis kandungan SOB dalam sampel pasir zirkon dari daerah Landak dan Tumbang Titi Kalimantan Barat serta Bangka menggunakan XRF. Berdasarkan kandungan SOB dalam pasir zirkon tersebut dapat diprediksi bahwa pasir zirkon dari daerah Landak dan Tumbang Titi Kalimantan Barat serta Bangka mengandung mineral zirkon $\left(\mathrm{ZrSiO}_{4}\right)$, ilmenit $\left(\mathrm{FeTiO}{ }_{3}\right)$, monasit (LREE, Th) $\mathrm{PO}_{4}$, dan senotim (HREE, Y, Th) $\mathrm{PO}_{4}$. Berbasis jenis mineral tersebut diperoleh hasil kajian berupa diagram alir proses konsep teknologi konsentrat zirkon menjadi $\mathrm{ZrO}_{2}$ (zirkonia) dan $\mathrm{ZrOCl}_{2} \cdot 8 \mathrm{H}_{2} \mathrm{O}$ (zirkonium oksiklorida) derajat industri serta zirkonia dan zirconium chemicals derajat nuklir, ilmenit menjadi $\mathrm{TiO}_{2}$, monasit menjadi $\mathrm{Nd}_{2} \mathrm{O}_{3}$ dan konsentrat $\mathrm{Th}(\mathrm{OH})_{4}$, senotim menjadi $\mathrm{Y}_{2} \mathrm{O}_{3}, \mathrm{Gd}_{2} \mathrm{O}_{3}$ dan konsentrat $\mathrm{Th}(\mathrm{OH})_{4}$ dalam satu kawasan pilot plant atau pabrik yang terintegrasi. Hasil kajian disimpulkan bahwa konsep pengolahan pasir zirkon lokal yang mengandung monasit, senotim, dan ilmenit dapat dilakukan secara terintegrasi dalam satu kawasan pabrik dengan hasil multi produk. Jika hal tersebut dapat direalisasikan di Indonesia dengan tambahan sistem pengolahan air limbah terpadu, maka selain aman bagi lingkungan juga dapat menghemat biaya produksi dan memberikan nilai tambah ekonomi bagi para pemegang izin usaha pertambangan zirkon.
\end{abstract}

Kata kunci:pengolahan, pasir zirkon, ilmenit, monasit, senotim

\begin{abstract}
The existence of zircon $\left(\mathrm{ZrSiO}_{4}\right)$ in the nature is mostly associated with some of the valuable oxide compounds (VOC), such as $\mathrm{TiO}_{2}$ and rare earth oxides (REO). The existence of natural minerals in Indonesia containing zirconium $(\mathrm{Zr})$ and REO lies in 13 regions, ranging from Aceh to West Papua province. Based on those aforementioned aspects, the goal of this research is to conduct the study of integrated technology of local zircon sand processing containing $\mathrm{TiO}_{2}$ and REO. The study was conducted by analyzing the content of VOC in zircon sand samples from the areas of Landak and Tumbang Titi West Kalimantan and Bangka by using XRF. Based on the content of VOC in this zircon sand, it can be predicted that the zircon sand from the area of Landak and Tumbang Titi West Kalimantan and Bangka contains mineral zircon $\left(\mathrm{ZrSiO}_{4}\right)$, ilmenite (FeTiO $\left.{ }_{3}\right)$, monazite (LREE, Th) $\mathrm{PO}_{4}$, and xenotime (HREE, Th) $\mathrm{PO}_{4}$. Based on these types of mineral, the flow chart of beneficiation technology process to increase the concentration of each mineral and the flow chart of zircon concentrate process into $\mathrm{ZrO}_{2}$ (zirconia) and $\mathrm{ZrOCl}_{2} \cdot 8 \mathrm{H}_{2} \mathrm{O}$ (zirconium oxychloride) industrial grade and zirconia and zirconium chemicals nuclear grade, ilmenite into $\mathrm{TiO}_{2}$, monazite into $\mathrm{Nd}_{2} \mathrm{O}_{3}$, and $\mathrm{Th}(\mathrm{OH})_{4}$ concentrate, xenotime into $\mathrm{Y}_{2} \mathrm{O}_{3}$, $\mathrm{Gd}_{2} \mathrm{O}_{3}$, and $\mathrm{Th}(\mathrm{OH})_{4}$ concentrate are obtained in one area of pilot plant or an integrated factory. The results of the study concluded that the concept of local processing of zircon sands containing monazite, xenotime, and ilmenite can be either integrated in the region with the results of multi-product plant. If it can be realized in Indonesia with the addition of an integrated waste water treatment system, then in addition to safe for the environment can also save on production costs and give economic added value for shareholders zircon mining permit.
\end{abstract}

Keywords:processing, zircon sand, ilmenite, monazite, xenotime 


\section{PENDAHULUAN}

Peningkatan nilai tambah sumberdaya alam (SDA) mineral Indonesia menjadi suatu keharusan sejak disahkannya UndangUndang Republik Indonesia Nomor 4 Tahun 2009 tentang Pertambangan Mineral dan Batubara (Minerba) yang telah diberlakukan Januari 2014 [1]. Melalui Peraturan Menteri ESDM Nomor 8 Tahun 2015 Pasal 4 Ayat (2), maka para pemegang izin usaha pertambangan (IUP) timah wajib melakukan pengolahan dan/atau pemurnian konsentrat zirkon, ilmenit, rutil, monasit, dan senotim. Selanjutnya dalam Lampiran I Permen ESDM tersebut telah diatur jenis dan batas minimum kadar beberapa produk pengolahan konsentrat zirkon, ilmenit, rutil, monasit, dan senotim menjadi zirconium chemicals, zirkonia, $\mathrm{Zr}$ sponge, REO, REOH, RE-metal, dan beberapa produk titanium yang berasal dari pertambangan pasir zirkon dan pasir timah yang boleh diekspor [2].

Keberadaan mineral zirkon $\left(\mathrm{ZrSiO}_{4}\right)$ di alam kebanyakan berasosiasi dengan beberapa mineral berharga seperti monasit, senotim, dan ilmenit. Keterdapatan zirkonium (Zr) dalam pasir zirkon dan rare earth element (REE) di Indonesia tersebar di 13 daerah seperti Sekuleh (Aceh), Sibolga (Sumatera Utara), Bangkinang (Riau), Pegunungan Tigapuluh (Riau/Jambi), Bangka-Belitung, Karimun-Kundur (Kepulauan Riau), Bukit Garba (Sumatera Selatan), Way Seputih (Lampung), Sambas (Kalimantan Barat), Tumbang Titi (Kalimantan Barat), Sungai Bunut/Long Laai (Kalimantan Timur), Takalar (Sulawesi Selatan), Pegunungan Arfak (Papua Barat), dan Ransiki (Papua Barat) [3].

Hasil analisis XRD terhadap sampel pasir zirkon +60 mesh yang diambil dari Pangkalanbun Kalimantan Tengah mengandung mineral monasit dan senotim dengan komposisi mineral: zirkon 32,08 \%, monasit 3,67 \%, senotim $0,34 \%$, kasiterit $16,97 \%$, ilmenit $0,69 \%$, rutil $1,38 \%$, magnetit $0,38 \%$, hematit $4,12 \%$, limonit 1,39\%, dan kuarsa 39,36 \% [4]. Lebih dari 450 sampel yang merupakan limbah penambangan pasir timah yang dikelola oleh PT Timah dan PT Koba Tin diambil dan dikumpulkan dari 6 lokasi seperti Nyelanding, Tobali, Sungkep, Bedukang, Jurung, dan Puput. Beberapa sampel tersebut dianalisis di Institut Keramik dan Bahan Bangunan Polandia dengan hasil analisis sampel ditunjukkan pada Tabel 1 [5].

Tabel 1. Komposisi mineral (\%) dalam limbah penambangan pasir timah dari 6 lokasi di Bangka.

\begin{tabular}{lcccccc}
\hline \multirow{2}{*}{ Mineral } & \multicolumn{5}{c}{ Komposisi mineral (\%) sampel } \\
& \multicolumn{7}{c}{ dari lokasi } \\
\cline { 2 - 7 } & $\mathbf{N}$ & $\mathbf{T}$ & $\mathbf{S}$ & $\mathbf{B}$ & $\mathbf{J}$ & $\mathbf{P}$ \\
\hline Monasit & 5,22 & 2,44 & 21,23 & 1,82 & 1,38 & 7,07 \\
Senotim & 1,78 & 3,27 & 17,55 & 1,01 & 0,56 & 1,13 \\
Zirkon & 7,32 & 18,69 & 16,92 & 10,69 & 1,33 & 62,82 \\
Rutil & 19,97 & 5,09 & 3,77 & 4,73 & 2,80 & 1,55 \\
Anatase & 1,92 & 0,34 & 0,92 & 3,16 & 4,82 & 0,11 \\
Pseudorutil & 41,70 & 28,93 & 7,19 & 38,68 & 37,64 & ND \\
Ilmenit & 2,35 & 9,16 & 16,90 & 4,12 & 3,15 & 8,79 \\
Kasiterit & 1,90 & 3,21 & 8,46 & 1,24 & 0,55 & 18,53 \\
Kuarsa & 17,80 & 24,65 & ND & 23,53 & 19,25 & ND \\
Pirit & ND & ND & 4,68 & 2,19 & ND & ND \\
Markasit & ND & ND & 2,39 & 2,42 & ND & ND \\
Turmalin & ND & 4,23 & ND & 6,42 & 18,69 & ND \\
Topas & ND & ND & ND & ND & 9,84 & ND \\
\hline Keterangan & N & Nyelanding, T & Tobali,
\end{tabular}

Keterangan: $\mathrm{N}=$ Nyelanding, $\mathrm{T}=$ Tobali, $\mathrm{S}=$ Sungkep, B = Bedukang, $\mathrm{J}=$ Jurung, $\mathrm{P}=$ Puput

ND: di bawah limit deteksi

Unsur logam tanah jarang atau rare earth elements (REE) terdiri dari 17 logam yang mana berisi scandium (Sc), yttrium $(\mathrm{Y})$, dan lantanida. Lantanida mempunyai 15 logam (lantanum sampai lutetium) dengan nomor atom 57 sampai 71 pada tabel periodik. Mineral monasit mengandung unsur tanah jarang ringan atau light rare earth elements (LREE) seperti La, Ce, Pr, Nd, Pm, Sm, Eu, 
dan Gd. Sedangkan mineral senotim mengandung unsur tanah jarang berat atau heavy rare earth elements (HREE) seperti $\mathrm{Tb}$, Dy, Ho, Er, Tm, Yb, dan Lu [6, 7].

Berdasarkan rumus kimia mineral monasit, maka mineral monasit mengandung bahan radioaktif alam atau naturally occuring radioactive materials (NORM) seperti $\mathrm{ThO}_{2}$ dan $\mathrm{U}_{3} \mathrm{O}_{8}$. Berdasarkan rumus kimia mineral ilmenit $\left(\mathrm{FeO} \cdot \mathrm{TiO}_{2}\right.$ atau $\mathrm{FeTiO}_{3}$ ), maka kandungan senyawa oksida berharga adalah $\mathrm{TiO}_{2}$. Ilmenit merupakan sumber titanium yang dapat berguna dalam industri pencampuran logam (alloy), selain itu karena sifatnya yang resisten terhadap panas dan korosi serta spesifik gravitasi yang rendah membuat logam ini (titanium) merupakan material yang penting dalam industri pesawat terbang [8]. Sejumlah metode yang telah banyak digunakan untuk membuat nanopartikel $\mathrm{TiO}_{2}$ antara lain: pengendapan kimia, mikroemulsi, reaksi hidrotermal, sol-gel, solvo thermal method, direct oxidation method, electro deposition, sonochemical method, dan microwave method [9 - 11]. Produk $\mathrm{TiO}_{2}$ telah banyak digunakan di industri cat, coating, dan filler karena mempunyai stabilitas tinggi, penyiapannya sederhana dan non toxic. Disamping itu, juga dipakai sebagai bahan semi-konduktor seperti perkakas opto-elektronik, sensor, dan $\mathrm{TiO}_{2}$ mempunyai sifat photocatalytic yang sangat baik [12]. $\mathrm{TiO}_{2}$ dengan energy band sekitar 3,2 eV mempunyai beberapa kegunaan, seperti optical coating, dye sensitized solar cell, sensor gas, heterogeneous catalysis, memory device [13 - 16]. Karena $\mathrm{TiO}_{2}$ mempunyai sifat non-toxic dan biocompatible, maka banyak digunakan dalam pengembangan biomedical science seperti rekayasa jaringan tulang [17]. Di bidang lingkungan hidup $\mathrm{TiO}_{2}$ digunakan sebagai fotokatalis untuk menangani pencemaran lingkungan, pemurnian air, pengolahan air limbah, pengendalian limbah berbahaya, dan pemurnian udara [18 - 25].

Konsentrat monasit yang sudah terpisah dari mineral zirkon, senotim, dan ilmenit, maka kandungan NORM di dalam mineral monasit lebih tinggi dibandingkan keberadaan NORM di dalam mineral senotim, zirkon, dan ilmenit seperti ditunjukkan pada Tabel 2 [26]. Berdasarkan kandungan thorium dan uranium yang tinggi dalam pasir monasit, maka mineral monasit oleh Peraturan Pemerintah No. 23 Tahun 2010 Pasal 2 Ayat (2)a adalah termasuk mineral radioaktif [27].

Tabel 2. NORM di dalam beberapa mineral alam

\begin{tabular}{lcccc}
\hline \multirow{2}{*}{ Mineral } & \multicolumn{2}{c}{ Thorium } & Uranium \\
\cline { 2 - 5 } Sebelum dibenefisiasi & $\mathbf{p p m}$ & $\mathbf{B q} / \mathbf{k g}$ & $\mathbf{B q}$ & $\mathbf{B g}$ \\
\hline Bijih mineral alam awal & $5-70$ & $40-600$ & $3-10$ & $70-250$ \\
\hline Setelah dibenefisiasi & & & & \\
\hline Konsentrat mineral berat & $80-800$ & $600-6600$ & $<10-70$ & $<250-1700$ \\
Ilmenit & $50-500$ & $400-4100$ & $<10-30$ & $<250-750$ \\
Rutil & $<50-350$ & $<400-2.900$ & $<10-20$ & $<250-500$ \\
Zirkon & $150-300$ & $1.200-2.500$ & $500-2.500$ & $3.700-7.400$ \\
Konsentrat monasit & $10.000-55.000$ & $80.000-450.000$ & $500-2500$ & $12.000-25.000$ \\
\hline
\end{tabular}


Eksplorasi pada endapan aluvial di sepanjang daerah aliran sungai Sekonyer, Mentaya, Katingan, Rungan, Kahayan, Muroi, Kapuas, dan lain-lain dengan total volume endapan sekitar 1,174 milyar $\mathrm{m}^{3}$ [28]. Hasil perhitungan eksplorasi diperoleh data sumber daya hipotetik pasir zirkon sekitar 6,5 juta ton dengan kandungan $\mathrm{ZrSiO}_{4}$ sekitar 2,6 juta ton. Sumberdaya hipotetik ini adalah sumberdaya yang sifatnya minimal, masih banyak wilayah-wilayah yang juga diketahui terdapat endapan zirkonnya tetapi masih belum masuk dalam perhitungan tersebut [28]. Pulau Kalimantan merupakan salah satu wilayah deposit mineral zirkon yang cukup besar di Indonesia dengan prediksi cadangan bijih zirkon di provinsi Kalimantan Tengah sekitar 5,4 milyar ton [29]. Limbah yang ditimbulkan dari pertambangan pasir timah oleh PT Timah di daerah Bangka Belitung antara lain pasir monasit, senotim, zirkon, dan ilmenit. Jumlah limbah dari penambangan pasir timah yang telah terkumpul selama ini antara lain 408.877 ton monasit (mengandung $50-78 \%$ REO), 57.488 ton senotim (mengandung 54 $65 \%$ REO), 309.882 ton zirkon (mengandung itrium dan cerium). Sementara itu, PT Koba Tin memiliki stok monasit 174.533 ton [30].

\section{Sukses Integrasi Pengolahan Mineral Alam yang Mengandung Zirkon, Monasit dan Ilmenit}

Dubbo Zirconia Project (DZP), Alkane Resources Ltd. di Australia telah sukses melakukan demonstration pilot plant pengolahan mineral yang mengandung $\mathrm{ZrO}_{2}$ $1,96 \%, \mathrm{HfO}_{2} 0,04 \%, \mathrm{Nb}_{2} \mathrm{O}_{5} 0,46 \%, \mathrm{Ta}_{2} \mathrm{O}_{5}$ $0,03 \%, \quad \mathrm{U}_{3} \mathrm{O}_{8} \quad 0,014 \%$, dan Total REO (TREO) 0,885 \%. Mineral tersebut kemudian diolah menjadi beberapa produk, antara lain: 15.827 ton $\mathrm{ZrO}_{2}, 1.967$ ton logam $\mathrm{Nb}, 3.997$ ton konsentrat LREO, dan 911 ton konsentrat
HREO. Total penjualan produk sebesar A\$ 503,5 juta dengan komposisi penjualan: $\mathrm{ZrO}_{2}$ $=\mathrm{A} \$ 153,9$ juta, logam $\mathrm{Nb}=\mathrm{A} \$ 81,5$ juta, konsentrat $\mathrm{LREO}=\mathrm{A} \$ 118,7$ juta, dan konsentrat $\mathrm{HREO}=\mathrm{A} \$ 149,4$ juta [31].

\section{Nilai Kandungan Ekonomis Strategis LTJ dalam Senotim di Bidang Industri Nuklir}

Unsur logam tanah jarang yang terkandung dalam pasir senotim mempunyai nilai ekonomis-strategis yang tinggi di bidang industri nuklir, maka perlu dilakukan pemisahan secara individual baik itrium itu sendiri maupun logam tanah jarang lainnya seperti: gadolinium (Gd), europium (Eu), dysprosium (Dy), erbium (Er), thulium (Tm), lutetium (Lu). Unsur Gd, Eu, Dy, Er, Tm, dan $\mathrm{Lu}$ berpotensi dapat digunakan sebagai batang kendali pada reaktor PLTN. Hal ini karena beberapa unsur tersebut mempunyai penampang lintang serapan neutron yang besar, antara lain: 46.000 barn (Gd), 4.300 barn (Eu), 950 barn (Dy), 173 barn (Er), 127 barn (Tm), 115 barn (Lu) [32].

Berdasarkan latar belakang, perumusan masalah, dan tinjauan pustaka, maka tujuan penelitian adalah membuat konsep integrasi teknologi pengolahan pasir zirkon lokal yang mengandung ilmenit, monasit, dan senotim.

\section{METODOLOGI}

Penelitian ini dilakukan dengan menggunakan metodologi sebagai berikut:

1. Penyediaan pasir zirkon dari daerah Tumbang Titi Kalimantan Barat dari pembelian melalui rekanan penyedia pasir zirkon, penyediaan pasir zirkon dari daerah Landak Kalimantan Barat yang diperoleh dari PT ANTAM (Persero) Tbk., penyediaan pasir zirkon yang merupakan limbah dari 
pertambangan pasir timah dari daerah Bangka yang diperoleh dari PT Timah.

2. Analisis senyawa oksida dalam sampel pasir zirkon dari daerah Tumbang Titi dan Landak Kalimantan Barat serta dari daerah Bangka menggunakan X-Ray Fluorescence (XRF).

3. Komparasi kandungan $\mathrm{ZrO}_{2}$, LREO, HREO dalam pasir zirkon lokal dan bijih zirkon (zircon ore) luar negeri.

4. Pembuatan konsep integrasi teknologi pengolahan bijih zirkon lokal yang mengandung zirkon, ilmenit, monasit, dan senotim dalam bentuk diagram alir proses berbasis tes metalurgi, pertimbangan prospek kebutuhan dan harga produk zirkonium, $\mathrm{TiO}_{2}$, LREO, dan HREO di pasar dunia.

\section{HASIL DAN PEMBAHASAN}

\section{Kandungan Senyawa Oksida dalam} Sampel Pasir Zirkon Lokal

Beberapa senyawa oksida yang terkandung dalam pasir zirkon lokal dari daerah Landak Kalimantan Barat [33], Tumbang Titi Kalimantan Barat serta daerah Bangka dilihat dari hasil analisis pasir zirkon dengan XRF di Pusat Survei Geologi Bandung seperti ditunjukkan pada Tabel 3. Nilai kadar pada Tabel 3 menunjukkan bahwa kandungan senyawa oksida berharga $\mathrm{La}_{2} \mathrm{O}_{3}, \mathrm{CeO}_{2}, \mathrm{Nd}_{2} \mathrm{O}_{3}$, dan $\mathrm{ThO}_{2}$ dalam pasir zirkon dari daerah Landak dan Tumbang Titi di Kalimantan Barat serta Bangka tersebut mengindikasikan bahwa kandungan senyawa oksida berharga di dalam pasir zirkon dari 3 daerah tersebut merupakan light rare earth element sebagaimana yang biasanya terdapat dalam mineral monasit. Hal ini sesuai dengan rumus kimia mineral monasit yang umumnya ditulis dengan (LREE, Th) $\mathrm{PO}_{4}$
[34 - 39]. Sementara itu, di dalam pasir zirkon dari daerah Bangka, selain mengandung LREE juga mengandung senyawa oksida berharga seperti $\mathrm{Y}_{2} \mathrm{O}_{3}$, $\mathrm{Pr}_{6} \mathrm{O}_{11}, \mathrm{Sc}_{2} \mathrm{O}_{3}, \mathrm{Dy}_{2} \mathrm{O}_{3}, \mathrm{Yb}_{2} \mathrm{O}_{3}, \mathrm{Er}_{2} \mathrm{O}_{3}$ yang merupakan high rare earth element yang biasanya terdapat dalam mineral senotim dengan rumus kimia yang biasa ditulis dengan (HREE, Y, Th) $\mathrm{PO}_{4}$ atau (Y, Th) $\mathrm{PO}_{4}$ [38].

Tabel 3. Kadar senyawa oksida berharga di dalam pasir zirkon lokal

\begin{tabular}{cccc}
\hline \multirow{2}{*}{$\begin{array}{c}\text { Senyawa } \\
\text { Oksida }\end{array}$} & \multicolumn{3}{c}{$\begin{array}{c}\text { Kadar Senyawa Oksida Berharga } \\
\text { dalam Pasir Zirkon, \% }\end{array}$} \\
\cline { 2 - 4 } & $\begin{array}{c}\text { Tumbang } \\
\text { Titi }\end{array}$ & $\begin{array}{c}\text { Landak } \\
{[33]}\end{array}$ & Bangka \\
\hline $\mathrm{ZrO}_{2}$ & 53,89 & 38,46 & 28,92 \\
$\mathrm{HfO}_{2}$ & 1,10 & 0,85 & 0,646 \\
$\mathrm{TiO}_{2}$ & 6,68 & 20,00 & 2,90 \\
$\mathrm{CeO}_{2}$ & 0,387 & 0,575 & 4,38 \\
$\mathrm{La}_{2} \mathrm{O}_{3}$ & 0,257 & 0,292 & 2,03 \\
$\mathrm{Nd}_{2} \mathrm{O}_{3}$ & 0,131 & 0,199 & 1,57 \\
$\mathrm{Sm}_{2} \mathrm{O}_{3}$ & - & - & 0,146 \\
$\mathrm{Pr}_{6} \mathrm{O}_{11}$ & - & - & 0,335 \\
$\mathrm{Sc}_{2} \mathrm{O}_{3}$ & - & - & 0,0064 \\
$\mathrm{Dy}_{2} \mathrm{O}_{3}$ & - & - & 0,0329 \\
$\mathrm{Yb}_{2} \mathrm{O}_{3}$ & - & - & 0,0562 \\
$\mathrm{Er}_{2} \mathrm{O}_{3}$ & - & - & 0,0205 \\
$\mathrm{Y}_{2} \mathrm{O}_{3}$ & 0,354 & 0,161 & 0,418 \\
$\mathrm{Total}_{\mathbf{R E}}$ & $\mathbf{1 , 1 2 9}$ & $\mathbf{1 , 2 2 7}$ & $\mathbf{8 , 9 9 5}$ \\
$\mathrm{ThO}_{2}$ & 0,1140 & 0,1100 & 1,190 \\
$\mathrm{U}_{3} \mathrm{O}_{8}$ & 0,0447 & 0,0464 & 0,189 \\
\hline
\end{tabular}

Berdasarkan hasil analisis senyawa oksida berharga $\left(\mathrm{ZrO}_{2}, \mathrm{HfO}_{2}, \mathrm{TiO}_{2}, \mathrm{REO}\right.$, $\mathrm{ThO}_{2}, \mathrm{U}_{3} \mathrm{O}_{8}$ ) yang terkandung dalam pasir zirkon dari 3 daerah (Tumbang Titi, Landak, Bangka) seperti terlihat pada Tabel 3, keterdapatan mineral monasit, senotim, ilmenit, dan zirkon yang terkandung dalam limbah pertambangan pasir timah Bangka pada Tabel 1, dan keberadaan monasit dan senotim dalam pasir zirkon Pangkalanbun Kalimantan Tengah [4] membuktikan bahwa kebanyakan pasir zirkon Indonesia 
berasosiasi dengan REE. Dengan demikian hasil analisis senyawa oksida berharga $\left(\mathrm{ZrO}_{2}, \mathrm{HfO}_{2}, \mathrm{TiO}_{2}, \mathrm{REO}, \mathrm{ThO}_{2}, \mathrm{U}_{3} \mathrm{O}_{8},\right)$ yang terkandung dalam pasir zirkon dari tiga (3) daerah (Tumbang Titi, Landak, Bangka) pada Tabel 3 dapat merepresentasikan bukti awal kebenaran berasosiasinya REE dan zirkonium di tigabelas (13) daerah di Indonesia mulai dari Aceh sampai Papua Barat seperti Sekuleh (Aceh), Sibolga (Sumatera Utara), Bangkinang (Riau), Pegunungan Tigapuluh (Riau/Jambi), Bangka-Belitung, KarimunKundur (Kepulauan Riau), Bukit Garba (Sumatera Selatan), Way Seputih (Lampung), Sambas (Kalimantan Barat), Tumbang Titi (Kalimantan Barat), Sungai Bunut/Long Laai (Kalimantan Timur), Takalar (Sulawesi Selatan), Pegunungan Arfak (Papua Barat), Ransiki (Papua Barat) [3].

Hasil analisis dengan XRF menunjukkan bahwa kandungan TREO dalam pasir zirkon dari daerah Tumbang Titi dan Landak Kalimantan Barat serta Bangka masing-masing 1,129 \%, 1,227 \%, dan $8,995 \%$ berat, sedangkan kadar $\mathrm{ZrO}_{2}$ masing-masing $53,89 \%, 38,46 \%$, dan $28,92 \%$. Untuk mengetahui kelayakan TREO dalam pasir zirkon lokal dapat diolah, maka perlu dikomparasi dengan kadar $\mathrm{ZrO}_{2}$, LREO, dan HREO dari beberapa proyek eksplorasi dan eksploitasi mineral alam di berbagai negara seperti ditunjukkan pada Tabel 4.

Berdasarkan hasil komparasi jumlah dan nilai kandungan TREO dalam pasir zirkon lokal dari daerah Tumbang Titi dan Landak Kalimantan Barat serta Bangka dengan TREO dalam mineral alam hasil proyek eksplorasi di berbagai negara pada Tabel 4, maka kandungan LREO dan HREO dalam pasir zirkon lokal relatif lebih besar daripada LREO dan HREO dalam bijih zirkon luar negeri. Agar kandungan LREO dan HREO dalam pasir zirkon lokal mempunyai nilai tambah ekonomi, maka diperlukan proses pemisahan pasir monasit yang mengandung LREO dan senotim yang mengandung HREO dari pasir zirkon $\left(\mathrm{ZrS}_{\mathrm{i}} \mathrm{O}_{4}\right)$ yang mengandung $\mathrm{ZrO}_{2}$ dan dari pasir ilmenit yang mengandung $\mathrm{TiO}_{2}$.

Tabel 4. Komparasi kandungan $\mathrm{ZrO}_{2}$, LREO, HREO dalam pasir zirkon lokal dan bijih zirkon luar negeri

\begin{tabular}{lccc}
\hline & \multicolumn{3}{c}{ Kandungan, \% berat } \\
\cline { 2 - 4 } Pasir zirkon lokal (Indonesia) & $\mathbf{Z r O}_{2}$ & LREO & HREO \\
\hline Tumbang Titi Kalbar & 53,89 & 1,129 & 0 \\
Landak Kalbar & 38,46 & 1,227 & 0,534 \\
Bangka & 28,92 & 8,461 & 0,34 \\
Pangkalanbun Kalteng [4] & 32,08 & 3,67 & $0,56-17,55$ \\
Bangka (PT Koba Tin \& PT Timah) di 6 lokasi [5] & $1,33-62,82$ & $1,38-21,23$ & 0,292 \\
\hline Bijih Zirkon Luar Negeri & & & 0 \\
\hline Dubbo Zirconia Project-Australia [31] & 1,96 & 0,593 & $0,053-0,343$ \\
Narraburra Project NSW-Australia [40] & 0,1250 & 0,0534 & 0,331 \\
REE Deposit, Sweden [41] & $0,33-2,01$ & $0,077-0,277$ & 1,516 \\
Nechalaco Canada [42] & 5,174 & \multicolumn{3}{c}{} \\
\hline
\end{tabular}

Untuk mengambil $\mathrm{ZrO}_{2}$ dari pasir zirkon, LREO dari pasir monasit dan HREO dari pasir senotim serta $\mathrm{TiO}_{2}$ dari pasir ilmenit, maka dilakukan proses benefisiasi untuk meningkatkan kadar senyawa oksida secara proses fisis (shaking table, magnetic 
separator, dan high tension separator) menjadi konsentrat zirkon dengan kandungan $\mathrm{ZrO}_{2}$ sekitar $65 \%$, konsentrat monasit dan senotim dengan kandungan TREO sekitar 40 - $50 \%$, dan konsentrat ilmenit dengan kandungan $\mathrm{TiO}_{2}$ sekitar 50 $\%$. Konsentrat zirkon, monasit dan senotim, serta ilmenit selanjutnya diolah secara proses kimia menjadi $\mathrm{ZrO}_{2}$, LREO dan HREO individual, serta $\mathrm{TiO}_{2}$ dengan kadar masing-masing di atas $99 \%$.

Dalam upaya untuk mengurangi senyawa oksida berharga tersebut ikut terekspor bersama pasir zirkon, maka data tersebut dapat menjadi masukan ke pembuat regulasi agar jumlah pasir zirkon yang masih mengandung monasit, senotim, dan ilmenit yang selama ini diekspor dapat dibatasi dan dikendalikan. Regulasi tersebut dapat menstimulasi para pengusaha yang mempunyai izin usaha pertambangan (IUP) zirkon di dalam negeri agar dapat melakukan benefisiasi pasir zirkon dengan cara yang baik dan benar sehingga dapat diperoleh konsentrat zirkon, monasit, senotim, dan ilmenit. Selanjutnya masingmasing konsentrat mineral tersebut dapat diolah secara proses kimia masing-masing menjadi zirconium chemicals, $\mathrm{ZrO}_{2}, \mathrm{HfO}_{2}$, $\mathrm{TiO}_{2}, \mathrm{REO}, \mathrm{U}_{3} \mathrm{O}_{8}$, dan $\mathrm{ThO}_{2}$ masing-masing dengan kadar $>99 \%$.

Pengolahan bijih zirkon (zircon ore) menjadi produk zirkonium seperti micronized zircon, zirconium chemicals, dan zirkonia stabil dan tidak stabil sampai dengan tahun 2020 cukup prospektif jika dilihat dari kenaikan permintaan produk zirkonium seperti ditunjukkan pada Tabel 5 [43]. Prediksi kenaikan permintaan produk zirkonium pada tahun 2020 diikuti dengan proyeksi kenaikan harga produk zirkonium seperti ditunjukkan pada Gambar 1 [44].
Tabel 5. Prediksi permintaan produk zirkonium.

\begin{tabular}{|c|c|c|c|c|}
\hline \multirow{2}{*}{$\begin{array}{l}\text { Produk } \\
\text { zirkonium }\end{array}$} & \multicolumn{4}{|c|}{$\begin{array}{c}\text { Permintaan produk zirkonium, } \\
\text { ton }\end{array}$} \\
\hline & 2011 & 2012 & 2015 & 2020 \\
\hline $\begin{array}{l}\text { Fused unstabilised } \\
\text { zirconia }\end{array}$ & 72.000 & 48.000 & 59.000 & 71.000 \\
\hline $\begin{array}{l}\text { Fused stabilised } \\
\text { zirconia }\end{array}$ & 25.000 & 17.000 & 21.000 & 25.000 \\
\hline Chemical zirconia & 40.000 & 27.000 & 33.000 & 40.000 \\
\hline Zirconium chemicals & 50.000 & 43.000 & 53.000 & 64.000 \\
\hline Total & 194.000 & 141.000 & 174.000 & 208.000 \\
\hline $\begin{array}{l}\text { Micronized zircon } \\
\text { dengan kadar } \mathrm{ZrO}_{2} \\
65 \%\end{array}$ & 300.000 & 217.000 & 268.000 & 320.000 \\
\hline
\end{tabular}

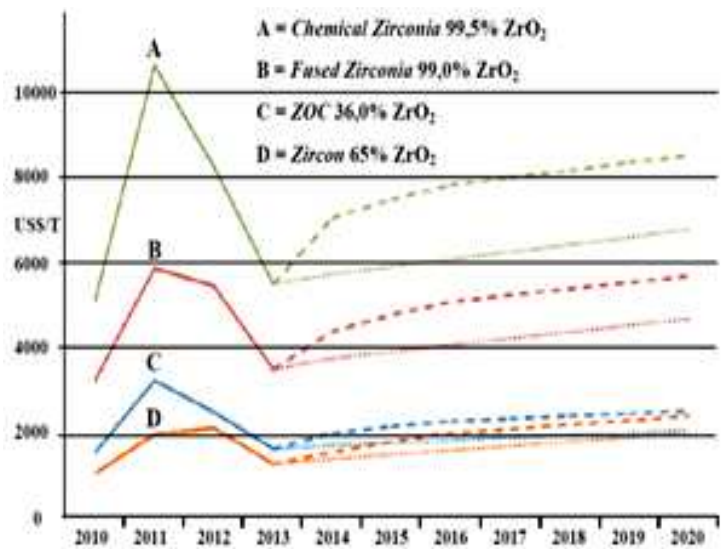

Gambar 1.Proyeksi harga produk zirkonium.

Harga REO di dunia dipengaruhi antara lain oleh fluktuasi persediaan dan kebutuhan (supply and demand). Beberapa produk REO individual di dunia saat ini yang mengalami kelebihan dan kekurangan persediaan seperti ditunjukkan pada Tabel 6 [45]. Jika dilihat pada Tabel 6, maka $\mathrm{La}_{2} \mathrm{O}_{3}, \mathrm{Ce}_{2} \mathrm{O}_{3}$, dan $\mathrm{Sm}_{2} \mathrm{O}_{3}$ di dunia mengalami surplus yang cukup signifikan sehingga sejak tahun 2011 sampai dengan 2015 harganya terus mengalami penurunan setiap tahun. Jika harga $\mathrm{La}_{2} \mathrm{O}_{3}$ dan $\mathrm{Ce}_{2} \mathrm{O}_{3}$ pada tahun 2015 dibandingkan dengan harga pada tahun 2011, maka penurunan harga $\mathrm{La}_{2} \mathrm{O}_{3}$ sekitar $2.500 \%$ dan penurunan harga $\mathrm{Ce}_{2} \mathrm{O}_{3}$ sekitar $2.000 \%$ seperti ditunjukkan pada Tabel 7 [46-55]. 
Tabel 6.Permintaan dan produksi REO individual di dunia (ton REO).

\begin{tabular}{lccc}
\hline \multicolumn{1}{c}{ REE } & Supply & Demand & Surplus/Shortage \\
\hline Lanthanum & 49.500 & 34.300 & 15.200 \\
Cerium & 77.750 & 70.500 & 7.250 \\
Praseodymium & 8.650 & 7.525 & 1.125 \\
Neodymium & $\mathbf{2 8 . 0 0 0}$ & $\mathbf{3 0 . 0 2 5}$ & $\mathbf{- 2 . 0 2 5}$ \\
Samarium & 3.275 & 1.150 & 2.125 \\
Europium & $\mathbf{4 5 0}$ & $\mathbf{5 0 0}$ & $\mathbf{- 5 0}$ \\
Gadolinium & $\mathbf{2 . 1 7 5}$ & $\mathbf{2 . 6 5 0}$ & $\mathbf{- 4 7 5}$ \\
Terbium & $\mathbf{2 5 0}$ & $\mathbf{5 0 0}$ & $\mathbf{- 2 5 0}$ \\
Dysprosium & 1.100 & 900 & 200 \\
Erbium & $\mathbf{5 5 0}$ & $\mathbf{1 . 0 5 0}$ & $\mathbf{- 5 0 0}$ \\
Yttrium & $\mathbf{7 . 3 0 0}$ & $\mathbf{1 3 . 6 0 0}$ & $\mathbf{- 6 . 3 0 0}$ \\
Ho-Tm-Yb-Lu & 1.000 & 250 & 750 \\
\hline \multicolumn{1}{c}{ Total } & $\mathbf{1 8 0 . 0 0 0}$ & $\mathbf{1 6 2 . 5 0 0}$ & \\
\hline
\end{tabular}

Tabel 7 menunjukkan bahwa produk LREO yang merupakan hasil pengolahan konsentrat pasir monasit mengalami penurunan harga yang cukup signifikan dibandingkan dengan penurunan harga produk HREO sebagai hasil pengolahan konsentrat pasir senotim. Produk LREO yang penurunan harganya kurang signifikan adalah $\mathrm{Nd}_{2} \mathrm{O}_{3}$ dan $\operatorname{Pr}_{6} \mathrm{O}_{11}$. Hal ini karena pasokan $\mathrm{Nd}_{2} \mathrm{O}_{3}$ di dunia mengalami kekurangan 2.025 ton/tahun [45] yang disebabkan oleh dominasi pemakaiannya sebagai bahan baku pada pembuatan magnet permanen dibandingkan dengan praseodymium (Pr), dysprosium (Dy), terbium (Tb), gadolinium (Gd), dan samarium (Sm) seperti ditunjukkan pada Gambar 2 [56].

Kebutuhan bahan logam $\mathrm{Nd}$ sebagai bahan bakupembuatan magnet permanen untukkeperluan energi yang ramah lingkungan pada 2015 - 2025 diprediksi semakin meningkat pada posisi 4 . Dengan demikian kekurangan persediaan bahan logam $\mathrm{Nd}$ sekitar 2.025 ton tersebut menyebabkan resiko suplai bahan logam $\mathrm{Nd}$ sampai dengan tahun 2025 berada pada posisi 3 seperti ditunjukkan pada Gambar 3 [57].
Tabel 7. Penurunan harga rare earth oxides (REO) di dunia sejak 2011.

\begin{tabular}{lccccc}
\hline \multirow{2}{*}{ REO } & \multicolumn{5}{c}{ Harga REO, US $\mathbf{/ k g}$} \\
\cline { 2 - 6 } & $\mathbf{2 0 1 1}$ & $\mathbf{2 0 1 2}$ & $\mathbf{2 0 1 3}$ & $\mathbf{2 0 1 4}$ & $\mathbf{2 0 1 5}$ \\
\hline $\mathrm{La}_{2} \mathrm{O}_{3}, 99,5 \%[46]$ & $50-52$ & $9-11$ & 6 & 5 & 2 \\
$\mathrm{Ce}_{2} \mathrm{O}_{3} 99,5 \%[46]$ & $40-45$ & $10-12$ & $5-6$ & $4-5$ & 2 \\
$\mathrm{Pr}_{6} \mathrm{O}_{11}[47,48]$ & 104,60 & 70,51 & 73,10 & 119 & 120 \\
$\mathrm{Nd}_{2} \mathrm{O}_{3} 99,5 \%[46]$ & $190-200$ & $75-80$ & $65-70$ & $56-60$ & $37-42$ \\
$\mathrm{Sm}_{2} \mathrm{O}_{3}[49]$ & 104,816 & 58,032 & 13,296 & 7,061 & 7,252 \\
$\mathrm{Gd}_{2} \mathrm{O}_{3}[51]$ & 62,724 & 24,167 & 24,033 & 25,485 & 26,046 \\
$\mathrm{Dy}_{2} \mathrm{O}_{3} 99,5 \%[46]$ & $1.400-$ & $600-$ & $440-$ & $320-$ & $215-$ \\
& 1.420 & 630 & 490 & 360 & 240 \\
$\mathrm{Eu}_{2} \mathrm{O}_{3} 99,5 \%[46]$ & $3.780-$ & $1.500-$ & $950-$ & $680-$ & $130-$ \\
$\mathrm{Tb}_{2} \mathrm{O}_{3} 99,9 \%[46]$ & 3.800 & 1.600 & 1.000 & 730 & 175 \\
$\mathrm{Ho}_{2} \mathrm{O}_{3}[51]$ & $2.800-$ & $1.200-$ & $800-$ & $590-$ & $410-$ \\
$\mathrm{Er}_{2} \mathrm{O}_{3}[52]$ & 303 & 1.300 & 850 & 640 & 490 \\
$\mathrm{Yb}_{2} \mathrm{O}_{3}[53]$ & 236 & 107 & 66 & 63 & 55 \\
$\mathrm{Lu}_{2} \mathrm{O}_{3}[54]$ & 81 & 113 & 63 & 71 & 62 \\
$\mathrm{Y}_{2} \mathrm{O}_{3}[55]$ & 143 & 111 & 26 & 21 & 21 \\
\hline
\end{tabular}

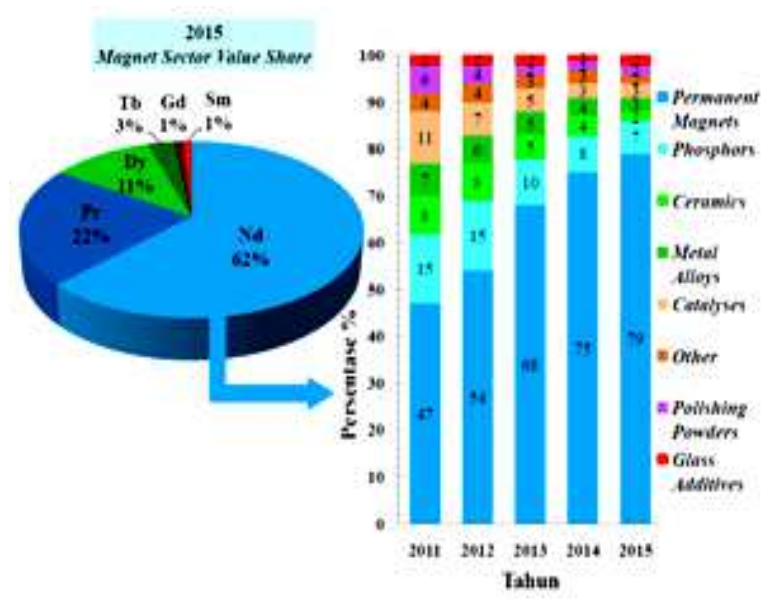

Gambar 2. Peningkatan kebutuhan Nd sebagai bahan baku pembuatan magnet permanen.

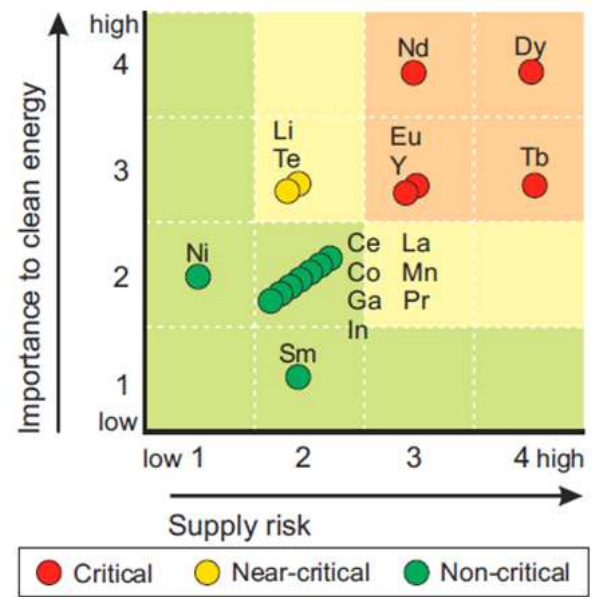

Gambar 3. Kritikalitas bahan logam 2015-2025. 
Pusat Teknologi Akselerator dan Proses Bahan-BATAN (PSTA-BATAN) cukup menguasai penelitian dan pengembangan teknologi proses pengolahan pada skala laboratorium terhadap:

1. Konsentrat pasir zirkon dari daerah Landak dan Tumbang Titi Kalimantan Barat menjadi $\mathrm{ZrO}_{2}$ dan $\mathrm{ZrOCl}_{2} .8 \mathrm{H}_{2} \mathrm{O}$ derajat industri [33, 58];

2. Konsentrat pasir ilmenit sebagai limbah benefisiasi pasir zirkon Tumbang Titi menjadi $\mathrm{TiO}_{2} 95 \%$ [59];

3. Konsentrat pasir monasit yang merupakan limbah padat dari pertambangan pasir timah di Bangka secara proses asam menjadi $\mathrm{Ce}_{2} \mathrm{O}_{3}$ dan $\mathrm{La}_{2} \mathrm{O}_{3}$ masing-masing dengan kadar> $99 \%$ dan $\mathrm{Nd}_{2} \mathrm{O}_{3}$ dengan kadar sekitar $90 \%$ [60].

4. Konsentrat pasir senotim yang merupakan limbah padat dari pertambangan pasir timah di Bangka menjadi $\mathrm{Y}_{2} \mathrm{O}_{3}$ dengan kadar sekitar 95 $\%$ dan hasil samping $\mathrm{Th}(\mathrm{OH})_{4}$.

\section{Pembahasan}

Pembuatan konsep integrasi teknologi pengolahan bijih zirkon lokal yang mengandung zirkon, ilmenit, monasit, dan senotim dalam bentuk diagram alir proses dapat dilakukan berdasarkan:

1. Hasil metallurigal test work pengolahan zirkon, ilmenit, monasit, dan senotim skala laboratorium yang telah berhasil dilakukan di PSTA BATAN.

2. Pertimbangan data prospek kebutuhan dan harga produk zirkonium, $\mathrm{TiO}_{2}$, LREO, dan HREO di pasar dunia saat sekarang dan prediksi sampai dengan tahun 2025.

3. Teknologi pengolahan bijih zirkon yang mengandung zirkon, ilmenit, monasit, dan senotim dilakukan dalam satu kawasan pilot plant atau pabrik yang berwawasan lingkungan dan hemat energi.

Berdasarkan tiga hal tersebut di atas, maka dapat dibuat diagram alir proses pembuatan produk zirkonium derajat industri dan nuklir dari konsentrat pasir zirkon, $\mathrm{Nd}_{2} \mathrm{O}_{3}$ dan $\mathrm{Th}(\mathrm{OH})_{4}$ dari konsentrat pasir monasit, $\mathrm{Y}_{2} \mathrm{O}_{3}, \mathrm{Gd}_{2} \mathrm{O}_{3}$ dan $\mathrm{Th}(\mathrm{OH})_{4}$ dari konsentrat pasir senotim, $\mathrm{TiO}_{2}$ dari konsentrat pasir ilmenit pada satu kawasan pilot plant atau pabrik seperti ditunjukkan Gambar 4-6.

Berbasis tahapan penelitian sebelumnya yang pernah dilakukan di PSTA-BATAN [41], konsentrat zirkon yang diperoleh dari benefisiasi pasir zirkon di lokasi pertambangan pada area B dikirim ke area C pada Gambar 4 untuk dijadikan sebagai bahan baku pada pengolahan secara proses kimia menjadi produk utama zirkonia, zirkonium oksiklorida derajat industri, zirkonia dan zirconium chemicals derajat nuklir menggunakan diagram alir proses seperti ditunjukkan pada Gambar 5. Konsentrat ilmenit yang diperoleh dari benefisiasi pasir zirkon pada area $\mathrm{B}$ dikirim ke area $\mathrm{C}$ untuk dijadikan sebagai bahan baku produk $\mathrm{TiO}_{2}$ (Gambar 5). Konsentrat monasit pada area B dapat dikirim sebagai bahan baku ke pabrik pada area $\mathrm{C}$ untuk diolah menjadi produk utama $\mathrm{Nd}_{2} \mathrm{O}_{3}$ dan hasil samping $\mathrm{Th}(\mathrm{OH})_{4}$ menggunakan diagram alir seperti ditunjukkan Gambar 6. Sementara itu, konsentrat senotim pada area $\mathrm{B}$ dapat dikirim ke $\mathrm{C}$ untuk diolah menjadi produk utama $\mathrm{Y}_{2} \mathrm{O}_{3}$ dan hasil samping $\mathrm{Th}(\mathrm{OH})_{4}$ menggunakan diagram alir proses (Gambar 6). 


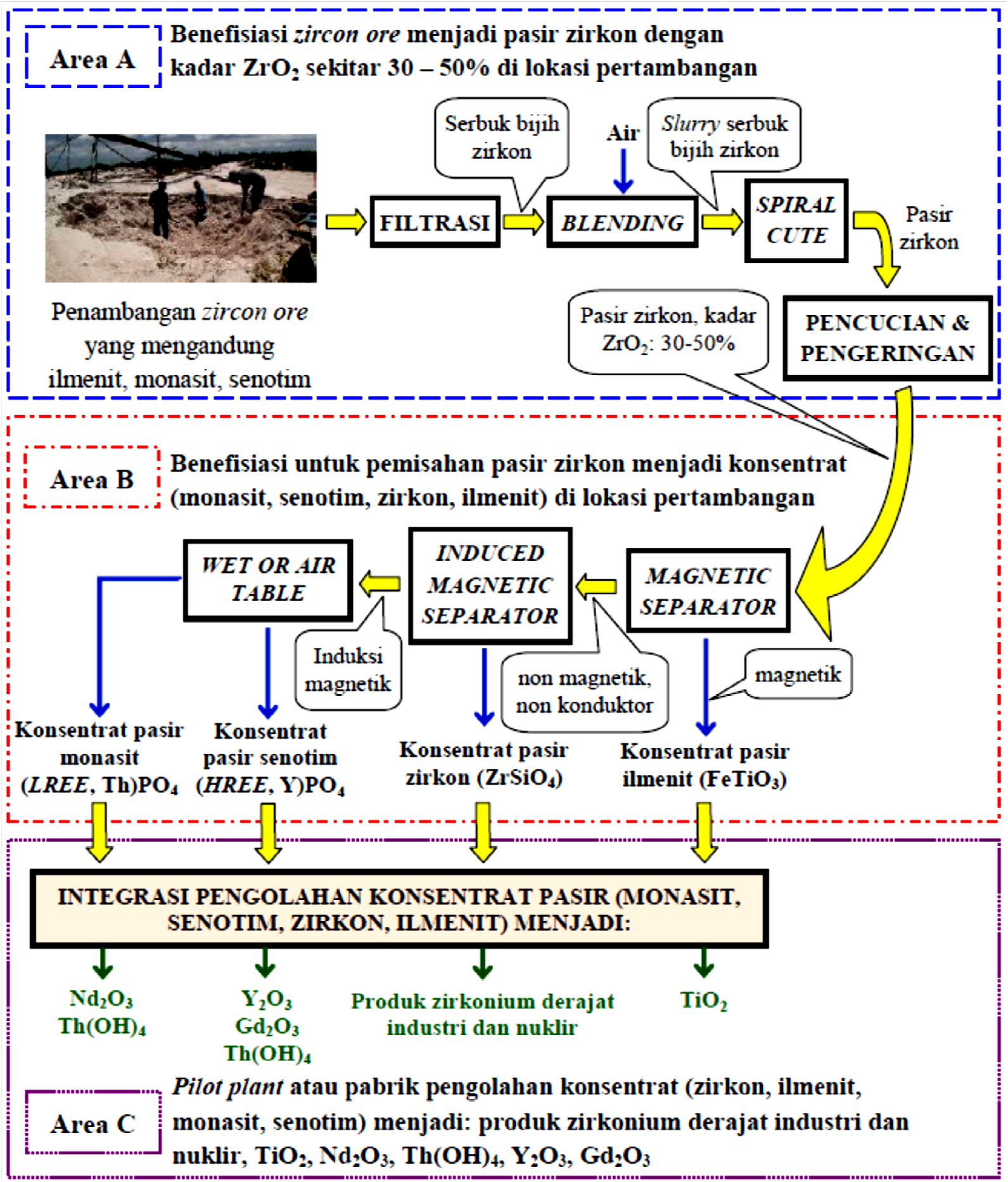

Gambar 4.Konsep integrasi teknologi pengolahan bijih zirkon yang mengandung zirkon, ilmenit, monasit, dan senotim menjadi produk zirkonium derajat industri dan nuklir, $\mathrm{TiO}_{2}, \mathrm{Nd}_{2} \mathrm{O}_{3}, \mathrm{Y}_{2} \mathrm{O}_{3}, \mathrm{Gd}_{2} \mathrm{O}_{3}$, dan $\mathrm{Th}(\mathrm{OH})_{4}$. 


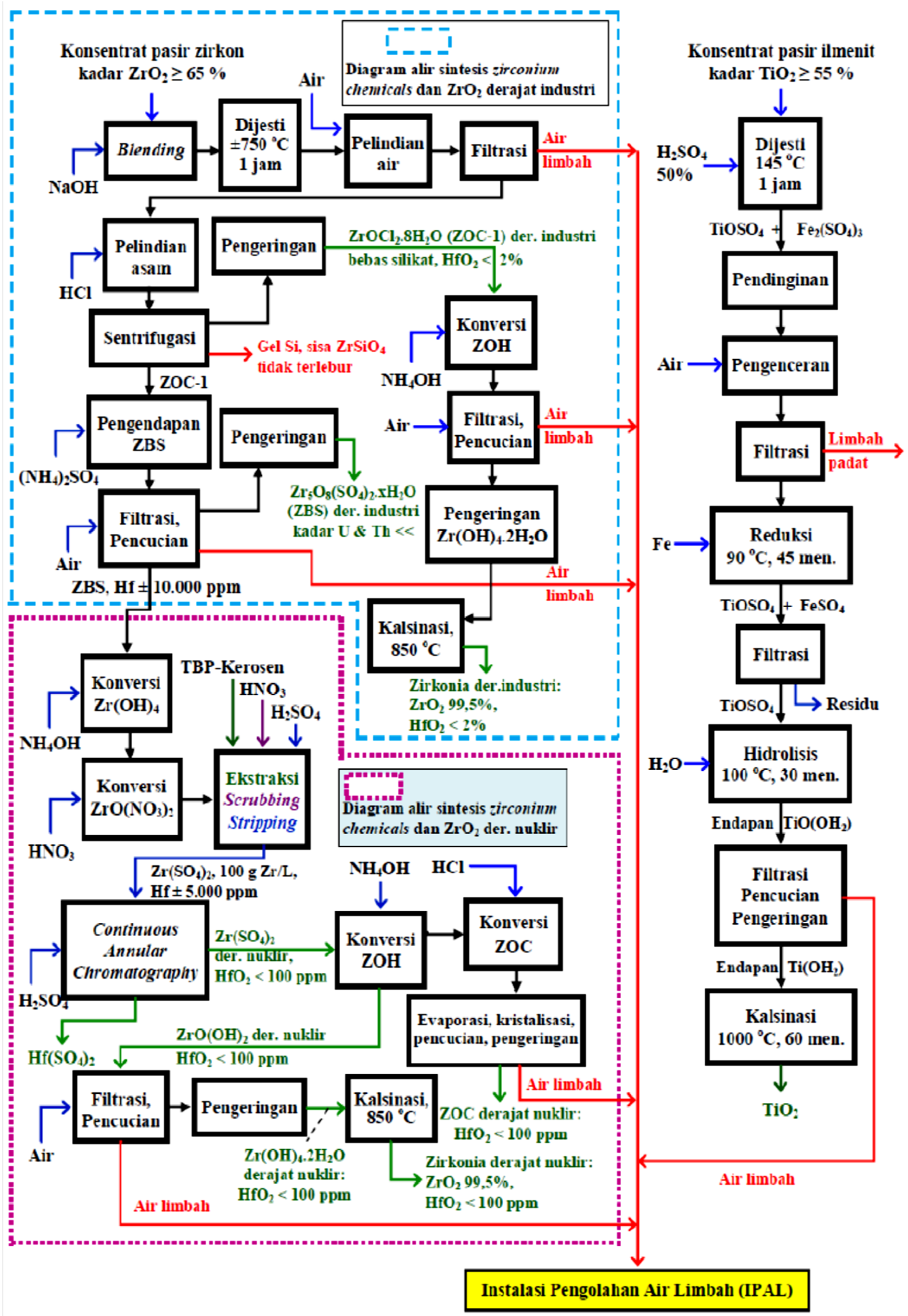

Gambar 5.Diagram alir konsep integrasi teknologi pengolahan konsentrat pasir zirkon dan ilmenit. 


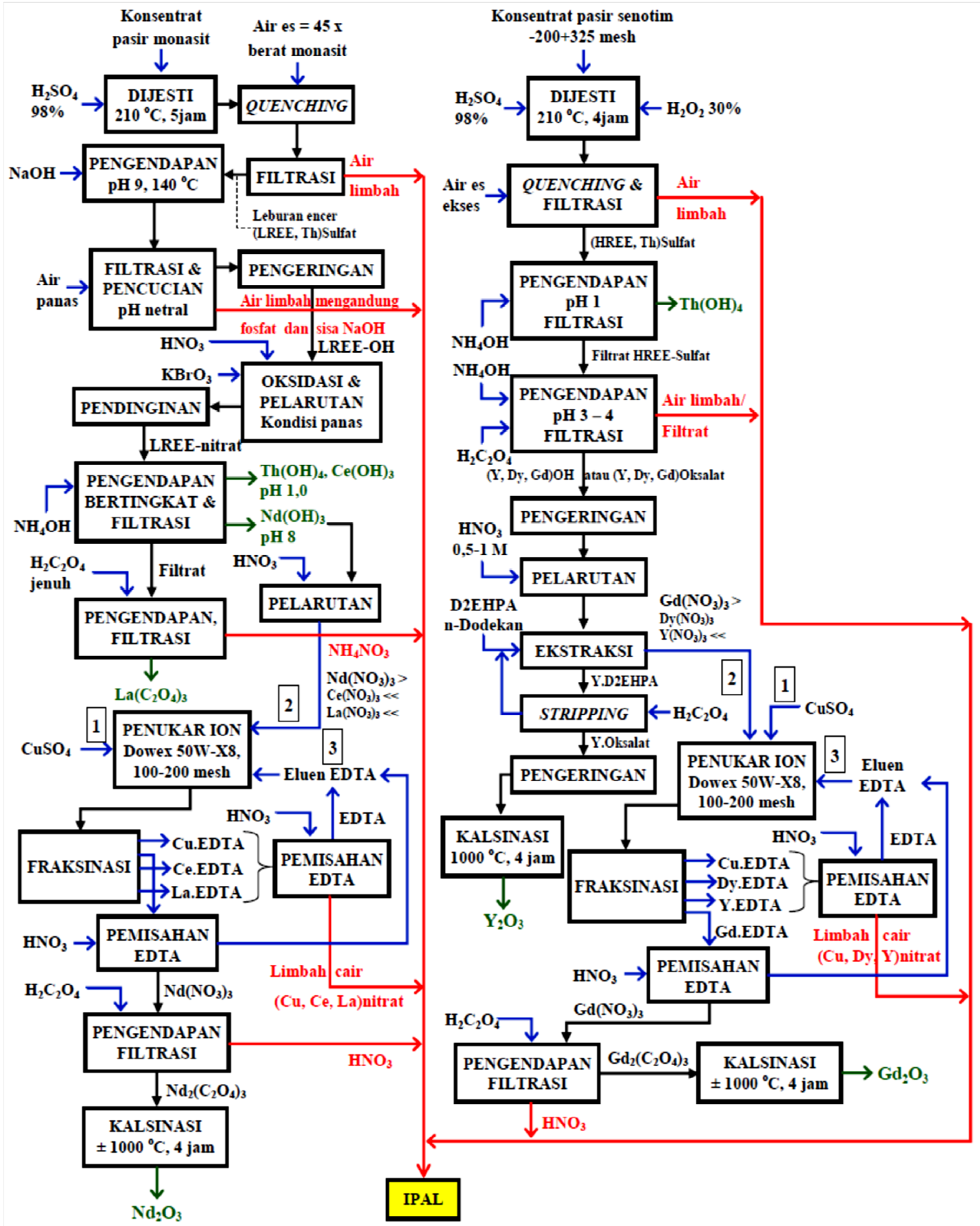

Gambar 6. Diagram alir konsep integrasi teknologi pengolahan konsentrat pasir monasit dan senotim.

Jika digunakan pilihan teknologi proses pengolahan konsentrat pasir zirkon menjadi zirkonia derajat nuklir dengan kadar $\mathrm{ZrO}_{2}$ 99,5\%, $\mathrm{HfO}_{2}<100$ ppm seperti ditunjukkan pada Gambar 5, maka kontribusi terhadap peningkatan nilai tambah pada industri pengolahan konsentrat pasir zirkon cukup signifikan. Hal ini disebabkan karena harga zirkonia derajat nuklir produksi Noah Technology Corporation di Texas USA sekitar 7,8 kali lipat dari harga zirkonia derajat industri dengan kemurnian 99,5\% $\mathrm{ZrO}_{2}$ dan kadar $\mathrm{Hf}<2 \%$ seperti ditunjukkan pada Gambar 7 [61]. 


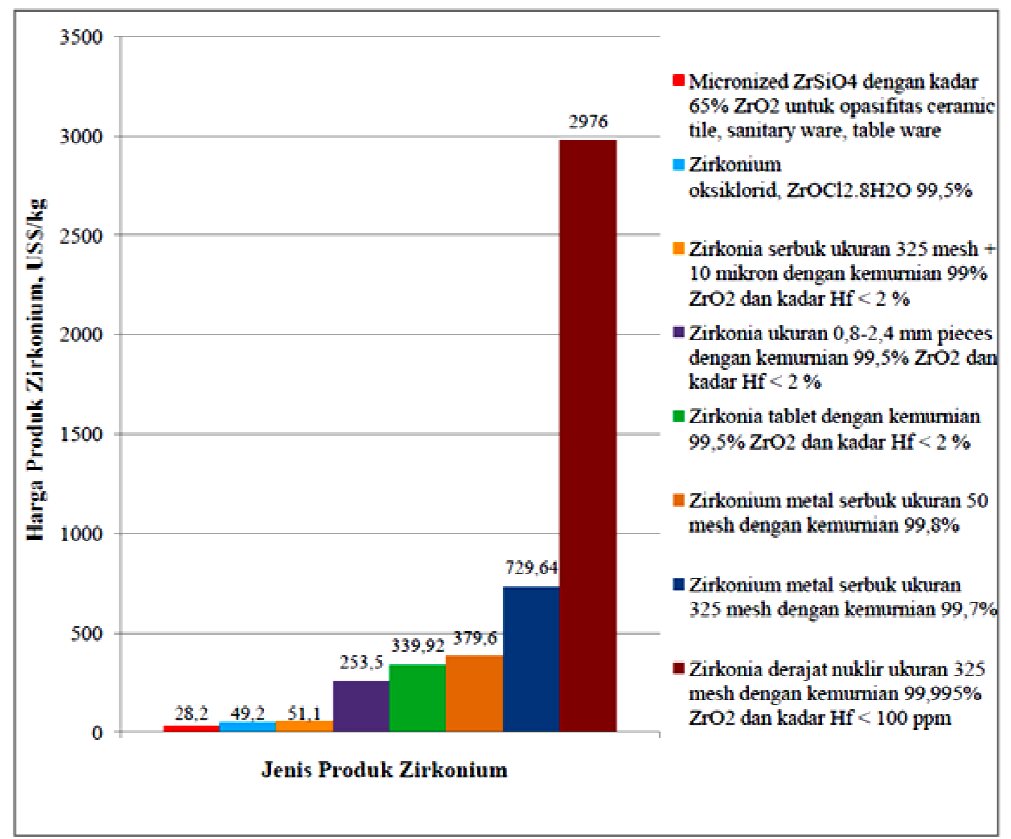

Gambar 7.Harga produk zirkonium produksi Noah Technology Corporation.

\section{KESIMPULAN}

Dari hasil penelitian dapat disimpulkan bahwa konsep pengolahan pasir zirkon lokal yang mengandung monasit, senotim, dan ilmenit dapat dilakukan secara terintegrasi dalam satu kawasan pabrik dengan hasil multi produk. Jika hal tersebut dapat direalisasikan di Indonesia dengan tambahan sistem pengolahan air limbah terpadu, maka selain aman bagi lingkungan juga dapat menghemat biaya produksi dan memberikan nilai tambah ekonomi bagi para pemegang izin usaha pertambangan zirkon.

\section{UCAPAN TERIMA KASIH}

Kami sampaikan terima kasih atas terlaksananya penelitian ini berkat pendanaan dari Insentif Riset SINas Konsorsium dengan judul "Pengembangan Teknologi Pengolahan Pasir Zirkon Lokal Indonesia menjadi Produk Zirkonium Grade Industri dan Nuklir untuk Mendukung MP3EI" pada tahun 2013 dan 2014 dan dari anggaran kerjasama Pusat Teknologi Akselerator dan Proses Bahan dengan PT ANTAM (Persero) Tbk. pada tahun 2012.

\section{DAFTAR PUSTAKA}

[1] Republik Indonesia, Pertambangan Mineral dan Batubara, Undang-Undang Republik Indonesia Nomor 4 Tahun 2009.

[2] Republik Indonesia, Perubahan atas Peraturan Menteri ESDM Nomor 1 Tahun 2014 tentang Peningkatan Nilai Tambah Mineral Melalui Kegiatan Pengolahan dan Pemurnian Mineral di Dalam Negeri, Peraturan Menteri ESDM Nomor 8 Tahun 2015.

[3] E. Suwargi, B. Pardiarto, dan T. Ishlah, "Potensi Logam Tanah Jarang di Indonesia," Buletin Sumber Daya Geologi, 5, 131-140, 2010.

[4] Y. Dahlan, Pramusanto, N. Saleh, E. Setyatmoko, S. Sumantri, dan E. Rahmawati, "Pembuatan Zirkonia dengan Metoda Peleburan Pasir Zirkon," Puslitbang Tekmira, 27, 2009.

[5] K. Szamafek, G. K. K. Zglinicki, and B. Marciniak-Maliszewsk, "New Potential Source of Rare Earth Elements," Gospodarka Surowcami Mineralnymi, DOI 10.2478/gospo-2013-0041, 2013.

[6] C. Jan and Bongaerts, "Production Process and Recycling of Rare Earth Elements," The IMRE Journal, 7, 1-9, 2013.

[7] G. J. Bryant, "Examining Perspectives on China's Near-Monopoly of Rare Earths," A Thesis Submitted in Partial Fulfillment of the 
Requirements for the Degree of Master of Arts in Asian Student, Florida International University, 9, 2015.

[8] D. P. Herman, "Potensi Mineral Cassiterite dan Ilmenite pada Daerah Bekas Penambangan Timah Bangka," Jurnal Promine, 3 (2), 30-41, 2015.

[9] T. Phonkhokkong, T. Thongtem, S. Thongtem, A. Phuruangrat, and W. Promnopas, "Synthesis and Characterization of $\mathrm{TiO}_{2}$ Nanopowders for Fabrication of Dye Sensitized Solar Cell," Digest Journal of Nanomaterials and Biostructures, 11 (1), 81-90, 2016.

[10] M. Hariharan, N. Varghese, and A. Benny Cherian, "Influence of Chitosan on the Surface Morphology of Titanium Dioxide Nano Particles," International Journal of Engineering Science \& Research Technology, 4 (9), 427-431, 2015.

[11] S. Bagheri, D. Ramimoghadam, A. Termeh, Yousefi, and S.B.A. Hamid, "Synthesis, Characterization and Electrocatalytic Activity of Silver Doped-Titanium Dioxide Nanoparticles," Int. J. Electrochem. Sci., 10, 3088-3097, 2015.

[12] Y. Z. Zeng, Y. C. Liu, Y. F. Lu, and J. C. Chung, "Study on the Preparation of Nanosized Titanium Dioxide with Tubular Structure by Hydrothermal Method and Their Photocatalytic Activity," International Journal of Chemical Engineering and Applications, 5 (3), 234-239, 2014.

[13] V. Vetrivel, K. Rajendran, and V. Kalaiselvi, "Synthesis and Characterization of Pure Titanium Dioxide Nanoparticles by Sol-gel Method, Int.J. ChemTech Res., 7(3),1090-1097, 2015.

[14] R. Sharmila Devi, R. Venckatesh, and R. Sivaraj, "Synthesis of Titanium Dioxide Nanoparticles by Sol-Gel Technique", International Journal of Innovative Research in Science, Engineering and Technology", 3 (8), 15206-15211, (2014).

[15] P. B. Rathod, K. R. Nemade, and S. A. Waghule, "Study of Structure and Optical for Chemically Synthesized Titanium Dioxide Nanoparticles," International Journal of Chemical and Physical Sciences, 4, 491-495, (2015).

[16] I. S. Kumar, M. Polasa, C. H. S. Chakra, and K. V. Rao, "Preparation and Characterization of Titanium Dioxide Nanoparticles by Olyvinylpyrrolidone, Hydrothermal Processes," International Journal of Multidiciplinary Advances Research Trends, 2 (1), 264-272, (2015).

[17] P. Tharanya, K. Vadakkan, J. Hemapriya, V. R. Kannan, and S. Vijayanand, "Biogenic Approach for the Synthesis of Titanium Dioxide Nanoparticles Using a Halophilic Bacterial Isolate - Chromohalobacter SalexigensStrain PMT-1," Int.J.Curr.Res.Aca.Rev., 3(10), 334-342, 2015.

[18] E. Kumar, D. M. Raj, S. C. Velladurai, S. K. Devi, and A. J. Begam, "Synthesis and Structural
Investigations of Titanium Di-oxide $\left(\mathrm{TiO}_{2}\right)$ Nanoparticles by Microwave Assisted Method," International Research Journal of Engineering and Technology, 02 (09), 458-461, 2015.

[19] D. Davis and C.R. Divya, "Reduction of Air Pollution from Vehicles Using Titanium Dioxide," International Research Journal of Engineering and Technology, 02 (05), 13081314, 2015.

[20] V. Chaudhary and P. S. Chaudhary, "Synthesis and Characterization of Titanium Dioxide Nanostructures based Photocatalysts for Degradation of Rose Bengal," International Journal of Innovative Science, Engineering \& Technology, 3 (6), 772-783, 2016.

[21] M. Bonnet, C. Massard, P. Veisseire, O. Camares, and K.O. Awitor, "Environmental Toxicity and Antimicrobial Efficiency of Titanium Dioxide Nanoparticles in Suspension," Journal of Biomaterials and Nanobiotechnology, 6, 213-224, 2015.

[22] S. S. Al-Taweel and H. R. Saud, "New Route for Synthesis of Pure Anatase $\mathrm{TiO}_{2}$ Nanoparticles Via Utrasound Assisted Sol-gel Method," Journal of Chemical and Pharmaceutical Research, 8 (2), 620-626, 2016.

[23] D. W. Skaf, A. M. Grannas, R. D. Weinstein, and R. Greeley, "Photocatalytic Oxidation of Dimethyl Methylphosphonate in Aqueous Suspensions of $\mathrm{TiO}_{2}$," J Chem Eng Process Technol, 6 (3), 2-6, 2015.

[24] Y. Tao, Z. Han, Z. Cheng, Q. Liu, F. Wei, K. E. Ting, and X. J. Yin, "Synthesis of Nanostructured $\mathrm{TiO}_{2}$ Photocatalyst with Ultrasonication at Low Temperature," Journal of Materials Science and Chemical Engineering, 3, 29-36, 2015.

[25] M. N. Chong, Z. Y. Tneu, P. E. Poh, B. Jin, and R. Aryal, "Synthesis, Characterisation and Application of $\mathrm{TiO}_{2}$-zeolite Nanocomposites for the Advanced Treatment of Industrial Dye Wastewater," Journal of the Taiwan Institute of Chemical Engineers, 1-9, 2014.

[26] World NuclearAssociation, "Naturally Occuring Radioactive Materials (NORM)," 2014. [Daring]. Laman: http://www.world-nuclear.org/info/ Safety-and-Security/Radiation-and-He. [Diakses: 05-Jan-2015].

[27] Republik Indonesia, Pelaksanaan Kegiatan Usaha Pertambangan Mineral dan Batubara, Peraturan Pemerintah Republik Indonesia No.23 Tahun 2010.

[28] D. Z. Herman, "Kemungkinan Sebaran Zirkon pada Endapan Placer di Pulau Kalimantan," Jurnal Geologi Indonesia, 2, 87-96, 2007.

[29] Sudarto, Kallista, dan D. Hermawan, "Kajian Teknis Aspek Pengawasan Bahan Nuklir dalam Pasir Zirkon," Prosiding Seminar Nasional Sains dan Teknologi-II 2008 Universitas Lampung, hal. IV-31 s.d. IV-38, 17-18 November, 2008. 
[30] "Indonesia Punya Cadangan Mineral Langka," 2012. [Daring]. Laman: http://energitoday.com/2012/10/03/ indonesiapunya-cadangan-mineral-langka/. [Diakses: 05Jan-2013].

[31] Alkane Resources Ltd., "The Pilot Plant: Key to Successful Process and Market, Development, Dubbo Zirconia Project," 2013. [Daring]. Laman: http://www.alkane.com.au/. [Diakses: 05-Jan2014].

[32] W. A. Rambeck, "Rare Earth Elements in Agriculture with Emphasis on Animal Husbandry," Inaugural-Dissertation zur Erlangung der Tiermedizinischen Doktorwürde, der Tierärztlichen Fakultät, der LudwigMaximilians-UniversitätMünchen, 25, 2006.

[33] H. Poernomo dan E. Susiantini, "Penilaian Teknologi Pembuatan Zirkonia dari Pasir Zirkon secara Proses Basah dan Kering," Prosiding Seminar Nasional Teknologi Energi Nuklir, hal. 601-614, 15-16 Oktober, 2015.

[34] M. V. Purwani dan Prayitno, "Ekstraksi Konsentrat Neodimium Memakai Tri Oktil Amin," Jurnal Iptek Nuklir Ganendra,17, 17-26, 2014.

[35] M. V. Purwani dan Prayitno, "Pemisahan Th dan Ce dari Konsentrat Serium Nitrat Hasil Olah Monasit dengan Cara Ekstraksi Bertingkat," J.Tek.Bhn.Nukl., 33-42, 2014.

[36] K. Binnemans and P. T. Jones, "Rare Earths and the Balance Problem,” J. Sustain. Metall, 2015.

[37] B. Arun, J. Varghese, K. P. Surendran, and M. T. Sebastian, "Microwave Dielectric and Thermal Properties of Mixed Rare Earth, Ortho phosphate [REmixPO4]," Ceramics International, 40, 13075-1308, 2014.

[38] R. L. Linnen, I. M. Samson, A. E. WilliamsJones, and A. R. Chakhmouradian, "Geochemistry of the Rare-Earth Element, Nb, Ta, Hf, and Zr Deposits," Elsevier Ltd., 543-564, 2014.

[39] S. C. Chelgani, B. Hart, and L. Xia, "A TOFSIMS Surface Chemical Analytical Study of Rare Erth Element Minerals from Micro-Flotation Tests Products," Minerals Engineering, 45, 3240, 2013.

[40] Capital Mining Ltd., "Resource Estimate Update Confirms Rare Earth Potential Narraburra Project," NSW, 09 November, 2011.

[41] M. Saxon, M. Leijd, K. Forrester, and J. Berg, "Geology, Mineralogy, and Metallurgical Processing of the Norra Kärr Heavy REE Deposit, Sweden," In: Symposium on Critical and Strategic Materials Proceedings, pp. 97-107, November 13-14, 2015.

[42] B. Guan and D. Yu, "Flotation Flowsheet Development for Avalon Rare Metal's
Nechalacho Deposit," Proceedings of the $52^{\text {nd }}$ Conference of Metallurgists (COM), pp. 115-132, October 27-31, 2013.

[43] Alkane Resources Ltd., "The Pilot Plant: Key to Successful Process and Market, Development, Dubbo Zirconia Project," Industrial Minerals International Conggress and Exshibition, Vancouver-Canada, 2014. [Daring]. Laman: http://www.alkane.com.au/. [Diakses: 03-Dec2014].

[44] Alkane Resources Ltd., "Annual General Meeting, Perth," 2013. [Daring]. Laman: http://www.alkane.com.au/. [Diakses: 05-Jan2014].

[45] Avalon Rare Metals Inc., "Annual Report December 02," IMCOA, 2012.

[46] U.S. Geological Survey, "Mineral Commodity Summaries," 2016. [Daring]. Laman: http://minerals.usgs.gov/minerals/pubs/commodit y/rare_earths/mcs-2016-raree.pdf. [Diakses: 01Jun-2016].

[47] "Strategic Metals \& Rare Earths Letter International," 2014. [Daring]. Laman: http://www.metalcommodities-ip.com/wpcontent/uploads/2015/10/SMRE_LETTER_ June2015Update.pdf. [Diakses: 05-Jan-2016].

[48] Argus Consulting Services, "Argus Rare Earths Monthly Outlook," Issue 14-11, November 3, 2014.

[49] "Samarium Oxide Price Worldwide from 2009 to 2025 (In U.S. Dollars per Metric Ton).” [Daring]. Laman:

http://www.statista.com/statistics/450155/globalreo-samarium-oxide-price-forecast/. [Diunduh: 05-Jun-2016].

[50] "Gadolinium Oxide Price Worldwide from 2009 to 2025 (In U.S. Dollars per Metric Ton)." [Daring]. Laman: http://www.statista.com/ statistics/450160/global-reo-gadolinium-oxideprice-forecast/. [Diakses: 05-Jun-2016].

[51] "Holmium Oxide Price Worldwide from 2010 to 2025 (In U.S. Dollars per Metric Ton).” [Daring]. Laman: http://www.statista.com/statistics/ 450166/global-reo-holmium-oxide-priceforecast/. [Diakses: 05-Jun-2016].

[52] "Erbium Oxide Price Worldwide from 2009 to 2025 (In U.S. Dollars per Metric Ton).” [Daring]. Laman: http://www.statista.com/statistics/ 450172/global-reo-erbium-oxide-price-forecast/. [Diakses: 05-Jun-2016].

[53] "Ytterbium Oxide Price Worldwide from 2010 to 2025 (In U.S. dollars per Kilogram)." [Daring]. Laman: http://www.statista.com/statistics/ 450173/global-reo-ytterbium-oxide-priceforecast/. [Diakses: 05-Jun-2016].

[54] "The Statistics Portal." [Daring]. Laman: http://www.statista.com/ statistics/450175/global- 
reo-lutetium-oxide-price-forecast/. [Diakses: 05Jun-2016].

[55] "Yttrium Oxide Price Worldwide from 2010 to 2025 (In U.S. Dollars per Kilogram).” [Daring]. Laman:

http://www.statista.com/statistics/450176/globalreo-yttrium-oxide-price-forecast/. [Diakses: 05Jun-2016].

[56] G. Scott, "Quarterly Activities Report and Appendix 5 B," Peak Resources Ltd., March 2016.

[57] G. J. Simandl and M. Neetz, "Which Materials are Critical and Strategic," Symposium on Critical and Strategic Materials Proceedings, p.3, November 13-14, 2015.

[58] H. Poernomo, E. Kismolo, dan E. Supriyatni, "Konsep Pengelolaan Limbah TENORM pada Pembuatan Zirkonium Oksiklorid dari Pasir
Zirkon," Prosiding Seminar Nasional Teknologi Energi Nuklir, hal. 379-390, 19 Juni, 2014.

[59] Suyanti dan M. V. Purwani, "Pembuatan $\mathrm{TiO}_{2}$ dari Ilmenit Tailing BenefisiasiMineral Zirkon," Prosiding Seminar Nasional Temu Ilmiah Jaringan Kerjasama Kimia Indonesia (Jasakiai), Seminar Nasional XXIV Kimia dalam Industri dan Lingkungan, hal. 181-211, 1 Februari, 2016.

[60] Suyanti, M. V. Purwani, dan Muhadi, "Peningkatan Kadar Neodimium secara Proses Pengendapan Bertingkat Memakai Amonia," Prosiding Seminar IV SDM Teknologi Nuklir, hal. 429-438, 25-26 Agustus, 2008.

[61] "High Purity Chemicals for Research and Production, Noah Technologies Corporation, 1 Noah Park San Antonio." [Daring]. Laman: http://www.noahtech.com/ frameset.asp?id=catalog_search. [Diakses: 19Mar-2012]. 